\title{
ULTRASTRUCTURAL EVIDENCE FOR RESORPTION OF SPERMATOZOA AND TESTICULAR FLUID IN THE EXCURRENT DUCTS OF THE TESTIS OF THE DOMESTIC FOWL, GALLUS DOMESTICUS
}

\author{
M. D. TINGARI* AND P. E. LAKE \\ Department of Veterinary Anatomy, University of Edinburgh, and \\ A.R.C. Poultry Research Centre, King's Buildings, West Mains Road, Edinburgh
}

(Received 1st November 1971, accepted 20th December 1971)

Summary. The fate of fowl spermatozoa and testicular fluid retained in the excurrent ducts, and some properties of the epithelial cells lining the ducts, were studied after ligation of the ductus deferens by light and electron microscopy. Striking changes occurred 3 or 4 weeks after ligation.

Spermatozoa accumulated cranial to the ligature chiefly in the lumina of the ductuli efferentes. They showed signs of disintegration mainly in the head where there was a disruption of chromatin and loosening of membranes. An increased amount of cell débris of unknown identity was also observed in the lumina of the ducts.

The uptake of spermatozoa by epithelial cells lining the male tract was seen in normal males but was much increased after ligation. The process was evident in the low cuboidal cells of the rete testis and in the ciliated and non-ciliated Type I cells lining the ductuli efferentes and narrow connecting ductules, and in the non-ciliated Type II cells lining the wide connecting ductules, ductus epididymidis and ductus deferens. Macrophages, containing spermatozoa, were found in the lumina of the ducts, in the subepithelial tissue and wedged between the basal lamina and the surface epithelia. All of these observations may indicate a route for the disposal of unejaculated spermatozoa in the male fowl.

Cytoplasmic vacuoles containing testicular fluid were seen in the apical parts of the ciliated cells and this may represent resorption of the fluid by these cells.

\section{INTRODUCTION}

A well-established function of the head of the epididymis, including the ductuli efferentes, in mammals is the absorption of some of the fluid produced in the seminiferous tubules (Setchell, 1970). Mammalian spermatogenesis has been

* Present address: Department of Anatomy, Faculty of Veterinary Science, University of Khartoum, Khartoum North, Sudan. 
described as a continuous process regardless of the frequency of ejaculation and degree of sexual activity (Simeone \& Young, 1931; Amann, 1962, 1970; Amann \& Almquist, 1962; Orgebin-Crist, 1965). Foote (1962) reviewed work which showed that the output of spermatozoa by the seminiferous tubules in mammals was more than could be obtained by the exhaustive ejaculation technique. This implies a natural loss of some spermatozoa in the male genital tract and interest has been expressed in the means of disposal of unejaculated spermatozoa. The two main routes so far considered in mammals are either voidance in urine (Oslund, 1928; Bielanski \& Wierzbowski, 1961; Lino, Braden \& Turnbull, 1967) or resorption in the excurrent ducts (Young \& Simeone, 1930; Young, 1931; Simeone \& Young, 1931; Amann \& Almquist, 1962; Glover, 1969; Paufler \& Foote, 1969).

Nicander (1963) and Crabo, Gustafsson, Nicander \& Rao (1971) reported briefly on the presence of fragments of spermatozoa intracellularly in the ductuli efferentes of a bull and in the epididymis of a rabbit. An electron microscopical study of Holstein (1967) revealed the presence of sections of spermatozoa in phagocytic cells in the lumen of the epididymis of man, which demonstrates another possible route for the disposal of some unejaculated spermatozoa. The present paper reports on an electron microscope examination of the activity of the epithelial cells lining the genital tract of the male fowl, Gallus domesticus, with regard to the resorption of seminal products under normal and experimental conditions.

A preliminary report (Tingari \& Lake, 1971) showed that the lining cells of the ductuli efferentes of the fowl were capable of taking up spermatozoa when the ductus deferens was ligated. Tingari (1971) gave a description of the normal anatomy of the genital tract of the male fowl.

\section{MATERIALS AND METHODS}

Genital tract tissue was studied in fourteen adult cocks; eight normal and six with a ligated ductus deferens. In each of the experimental males, laparotomy was performed under an anaesthetic (Nembutal, Abbott Laboratories Ltd) and unilateral ligatures were applied to one ductus deferens (see Text-fig. 1), either at its junction with the epididymal region, cranial ligature, or near its midpoint, caudal ligature; the other side was left as a control.

The birds were killed at intervals of 1, 3, 4, 6 and 8 weeks after the operation when the gross morphological changes on the two sides were compared in each bird.

To prepare the genital tract tissue for microscope examination, most of the abdominal organs were removed leaving the reproductive tract to be fixed for a few minutes in situ by filling the cavity with ice-cold fixative. The tract was then dissected out and small pieces from the epididymal region and ductus deferens some distance cranial to the site of ligation were transferred to fresh fixative so that the total fixation time did not exceed $30 \mathrm{~min}$. The fixative used was a mixture of $4 \%$ formaldehyde and $0.8 \%$ glutaraldehyde in phosphate buffer at $\mathrm{pH} \mathrm{7.4}$. Postosmication was carried out for $1 \mathrm{hr}$ in $1 \%$ osmium tetroxide in phosphate buffer (Millonig, 1962). The tissues were then dehydrated in 
ethanol, cleared in propylene oxide and embedded in Araldite by conventional methods.

Thick sections ( $1 \mu \mathrm{m}$ thick), cut with glass knives, were stained with toluidine blue and examined with the light microscope. The desired regions for electron microscopy were selected and thin sections, cut with diamond or glass knives, were mounted on uncoated copper grids, stained with alcoholic uranyl acetate (Stempak \& Ward, 1964) followed by lead citrate (Reynolds, 1963) and examined on an AEI EM 6B electron microscope.

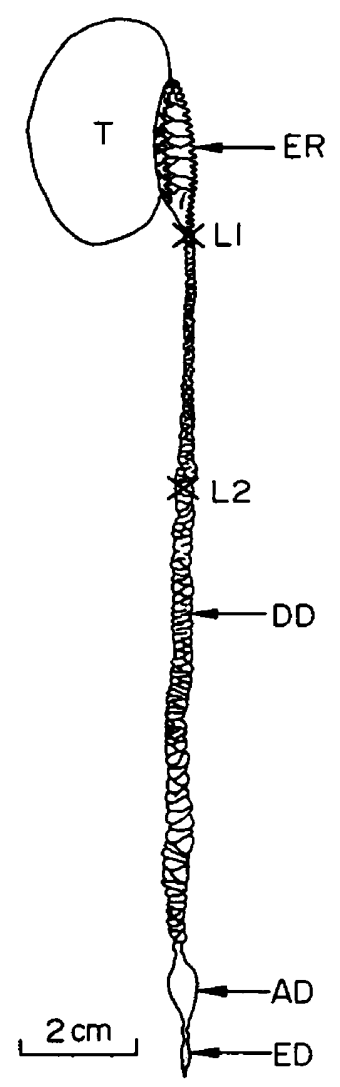

TEXT-FIG. 1. A diagrammatic representation of the reproductive tract of the male domestic fowl: $T$, testis; ER, epididymal region (comprising rete testis, connecting ductules and ductus epididymidis); DD, ductus deferens; AD, ampulla of ductus deferens; ED, ejaculatory duct which protrudes into the cloaca. See Tingari (1971) for detailed anatomical description. L1 and L2 denote sites of cranial and caudal ligatures respectively.

Samples of tissue were also fixed in Bouin's fluid, processed for paraffin wax sections and stained with haematoxylin and eosin for examination by light microscopy.

\section{RESULTS}

Gross observations showed that, up to 4 weeks after ligation, the experimental 
testis was only slightly enlarged. After longer periods of ligation, there did not appear to be any accelerated increase in size.

Prominent creamy-coloured streaks converging on the epididymal region were seen through the membrane covering the testicular parenchyma of the ligated side; this was due to the accumulation of spermatozoa in the seminiferous tubules before their entry into the excurrent duct system.

The epididymal region in all cases was slightly larger on the experimental side than on the control when cranial ligatures (Text-fig. 1) were used. When the ligatures were placed more caudally (Text-fig. 1), the seminal products accumulated in the entire duct system cranial to the site of ligation. In these cases, the caudal, or remaining parts of the ductus deferens, were empty and flaccid.

\section{EXPLANATION OF PLATES 1 TO 5}

\section{PLATE 1}

Frg. 1. Rete testis showing spermatozoa in the lumen. Cells (arrowed), possessing eosinophilic granules, occur in both the epithelial lining and in the lumen of the rete tubule of a cock (Gallus domesticus). Haematoxylin and eosin. $\times 466$.

Fig. 2. An efferent ductule showing vacuolation between cells in the epithelium. Toluidine blue. $\times 1307$.

Fig. 3. Accumulation of seminal fluid and spermatozoa in the lumen of an efferent ductule 3 weeks after cranial ligation. Note the disruption of chromatin (single arrows) in the heads of some spermatozoa and the absence of distinct membranes around most of the spermatozoa (double arrows). $\times 9334$.

\section{PLATE 2}

Fig. 4. The lumen of an efferent ductule 3 weeks after caudal ligation showing a free luminal cell surrounded by spermatozoa. Many cytoplasmic vacuoles containing spermatozoa (white arrows) and products of their breakdown are seen within the cell. $\times 9334$.

Fig. 5. Macrophage in the lumen of the rete testis 4 weeks after caudal ligation. Note the pseudopodia-like processes of the cell, its content of rough endoplasmic reticulum and the sperm-containing cytoplasmic vacuoles. $\times 14,000$.

\section{PLATE 3}

Frg. 6. Rete epithelium showing the uptake of spermatozoa (arrowed) 3 weeks after caudal ligation. $L$, lumen. B, basal lamina. $\times 18,667$.

FIG. 7. Uptake of spermatozoa (arrowed) by the ciliated cells lining an efferent ductule 3 weeks after ligation. Note the intact junctional complexes $(\mathrm{J})$ between cells and cilia $(\mathrm{C})$. $\times 14,000$.

Fig. 8. Epithelium of an efferent ductule 3 weeks after cranial ligation. Note sections of spermatozoa (arrowed) in definite cytoplasmic vacuoles of a non-ciliated Type $I$ cell. L, lumen. $\times 14,000$.

\section{PLATE 4}

Fig. 9. Spermatozoa (arrowed) surrounded by microvilli at the surface of a non-ciliated Type II cell in the ductus epididymidis of a normal tract. $\times 42,000$.

FIG. 10. Epithelial lining of an efferent ductule after 3 weeks of cranial ligation. Note the wide intercellular spaces and the contained spermatozoa (arrows). All the cells are healthy and there are no signs of separation of the junctional complexes $(\mathrm{J}) . \times 9334$.

\section{PLATE 5}

Frg. 11. A macrophage, containing spermatozoa, in the subepithelial tissue of a connecting ductule seen 3 weeks after cranial ligation. Basal lamina, L; Surface epithelia, S. $\times 14,000$. Frg. 12. A large fluid-containing vacuole $(V)$ in the apical cytoplasm of a ciliated cell of an efferent ductule 3 weeks after cranial ligation. The consistency and electron opacity of the vacuolar fluid is similar to that of the seminal fluid in the lumen $(L) . \times 14,000$. 

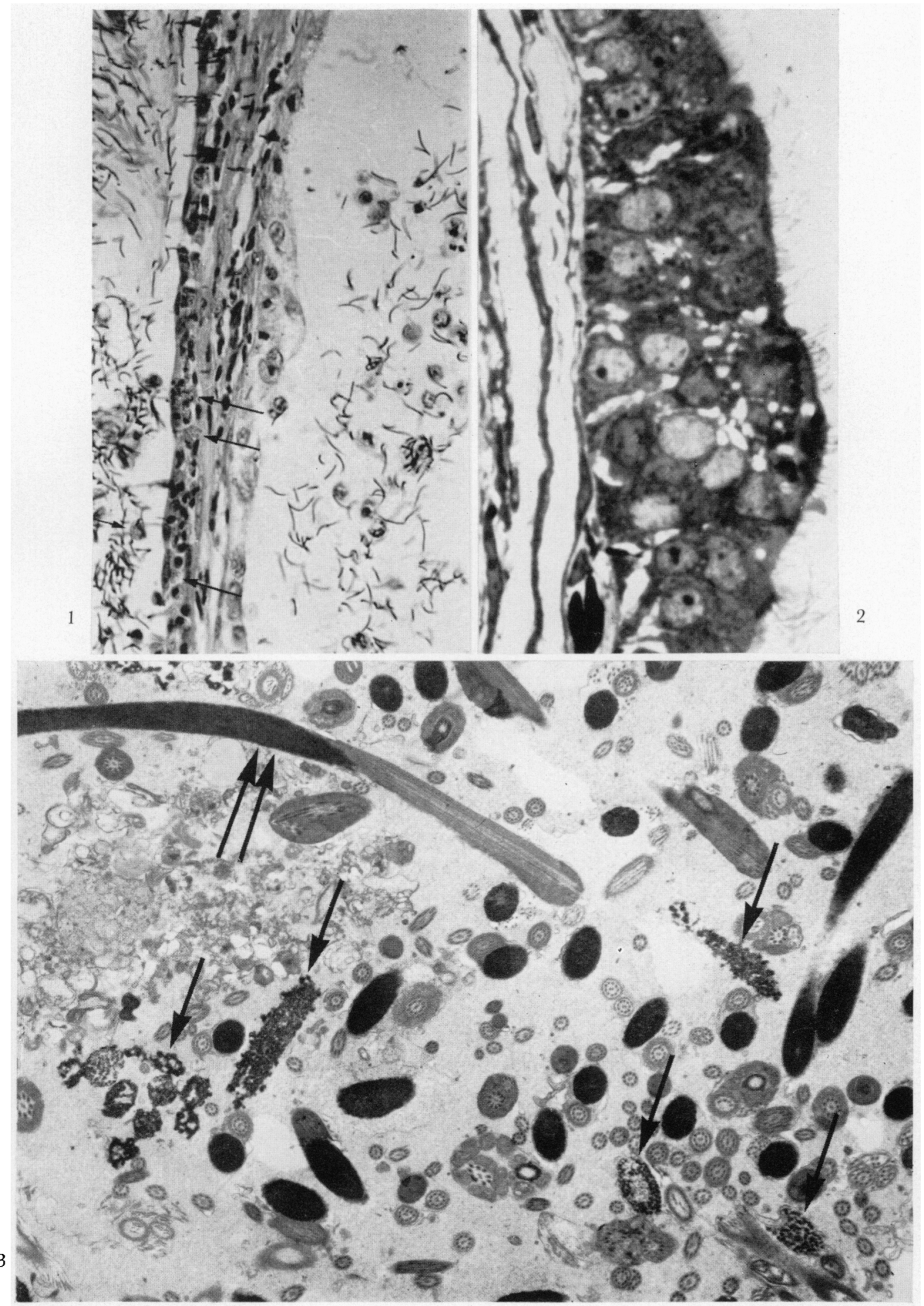

(Facing 1. 376) 


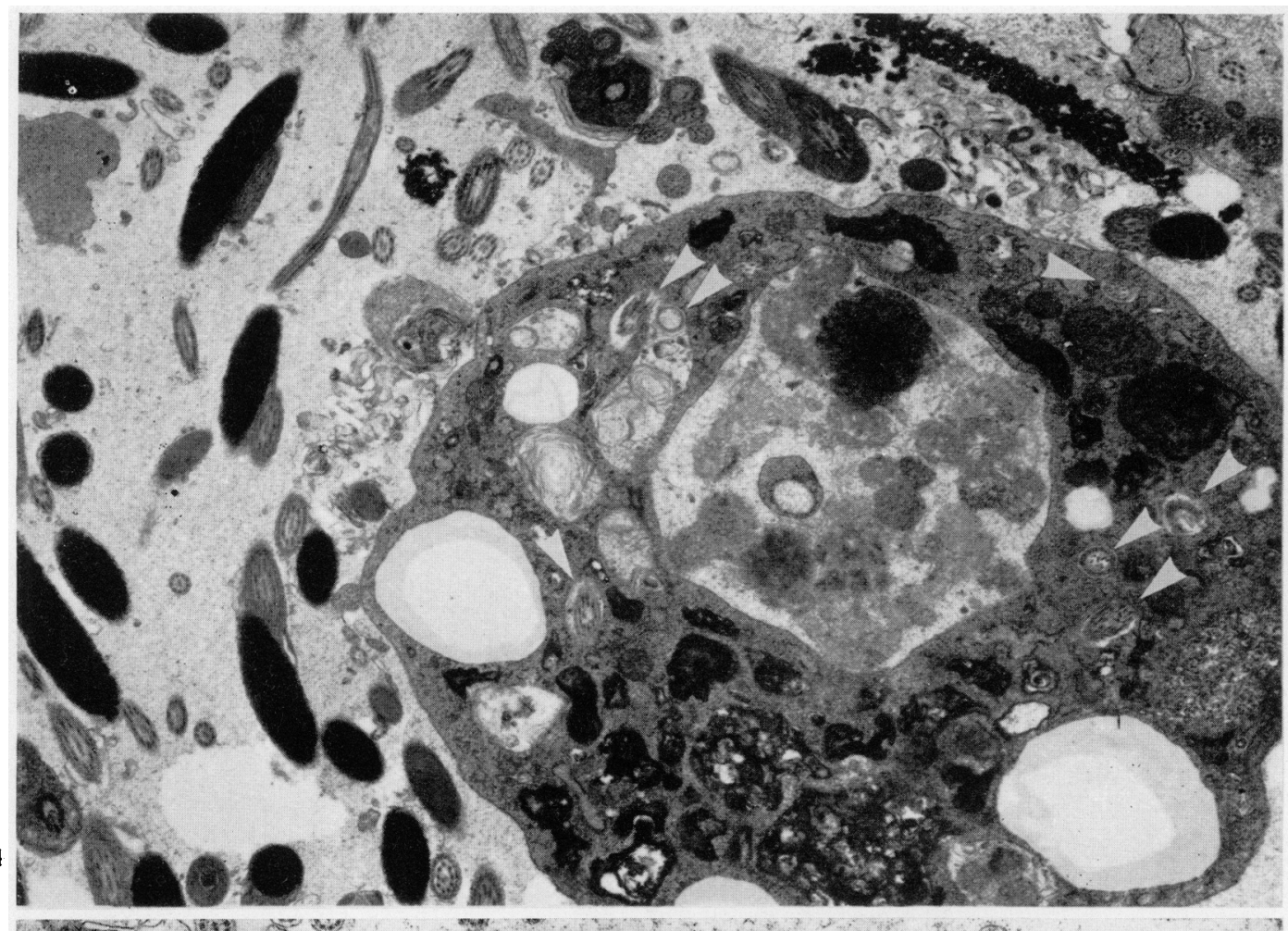

158. 00.25

r. $0.090^{\circ}, y \cdot 0$

$-10 \% 0$ a

${ }_{0}^{9}, 0^{2}-$

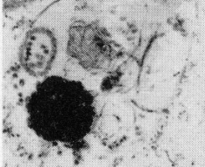

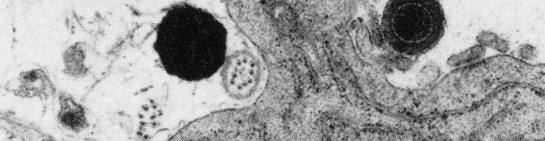

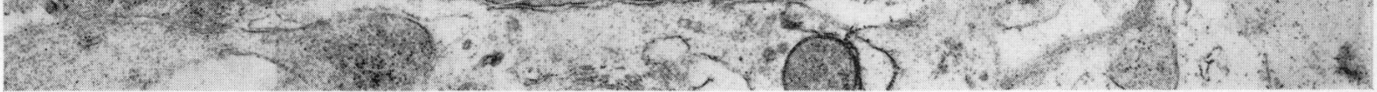


PL V'E 3

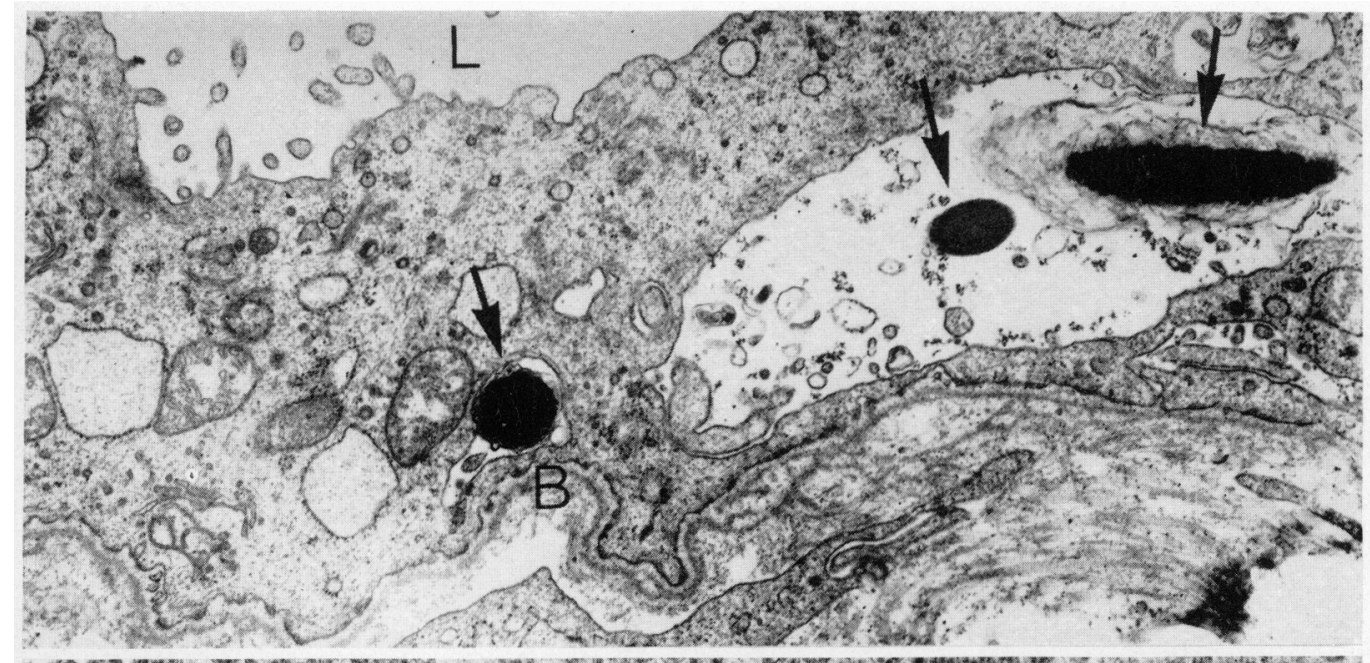

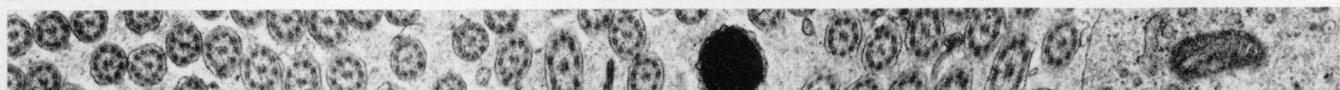

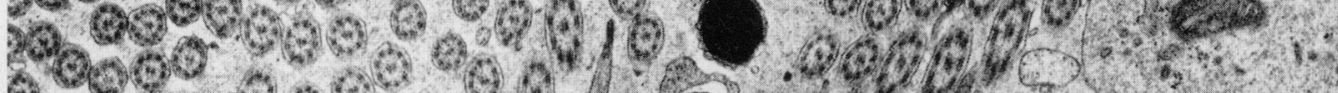
$0000000^{\circ} 00.09 \%$

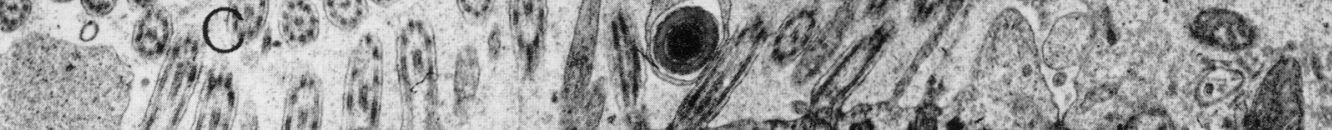

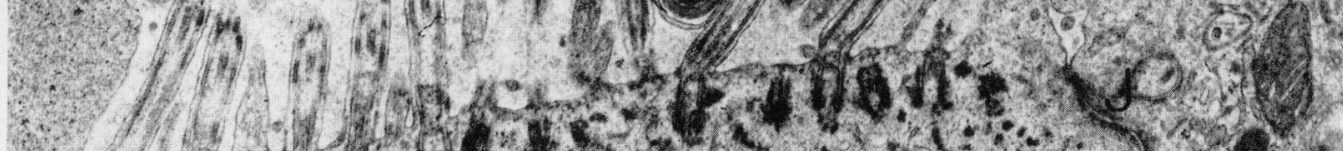

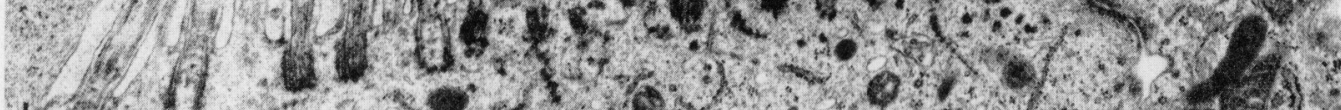

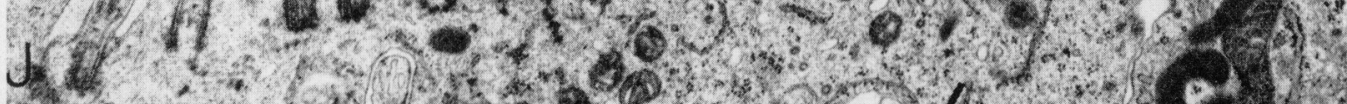

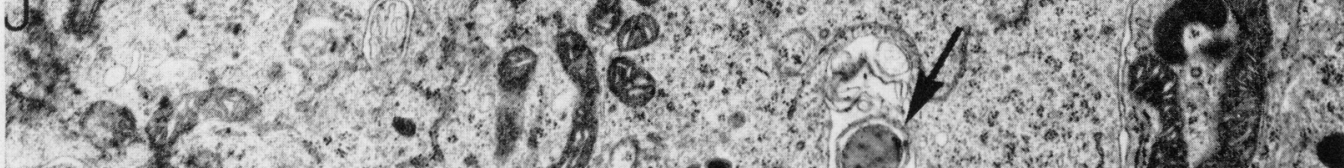

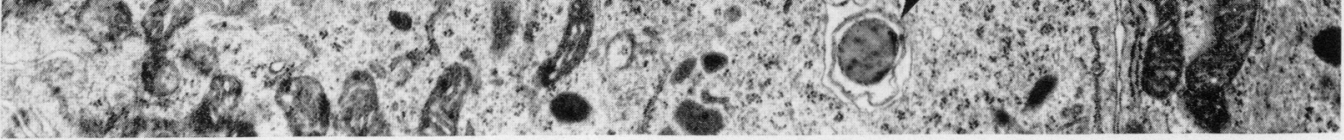

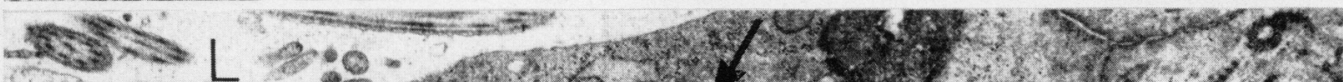

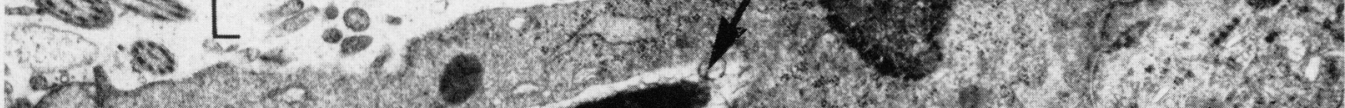
25. 


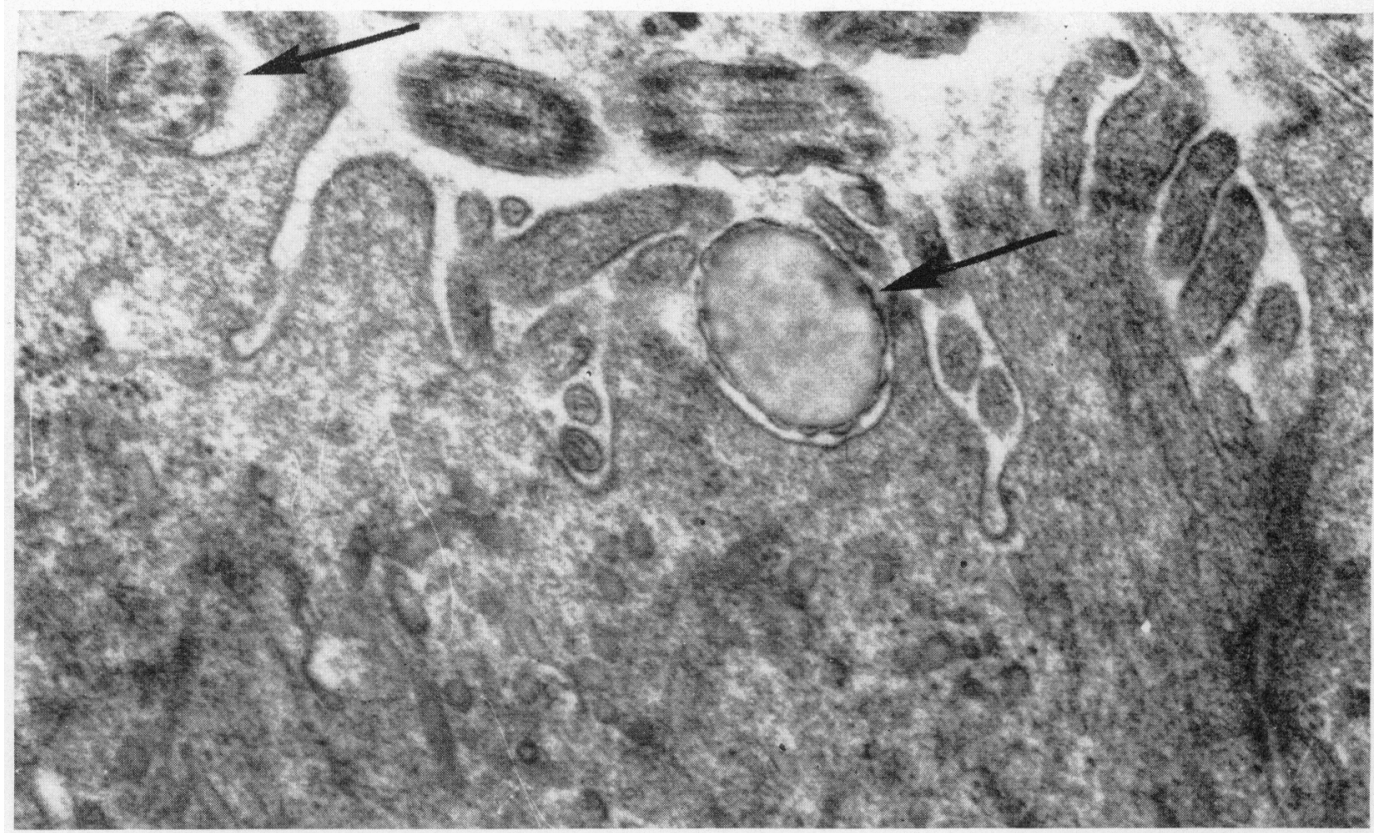

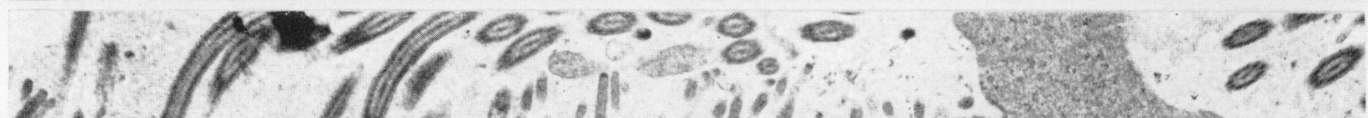

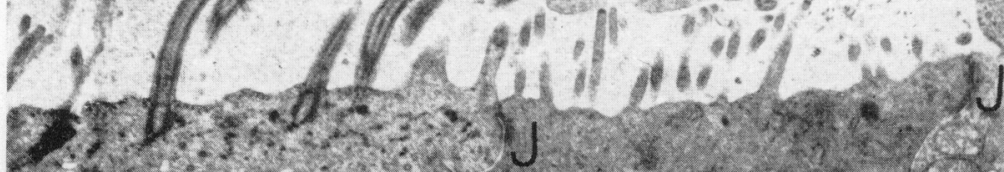

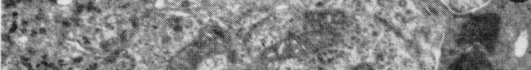

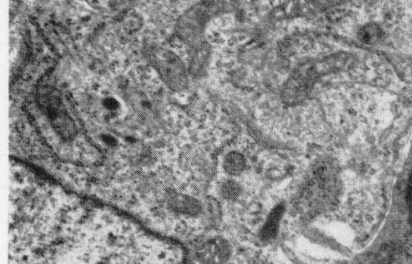

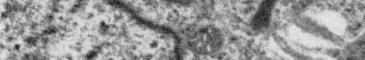

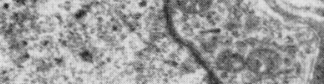

$x^{2}-2,-3 \times$

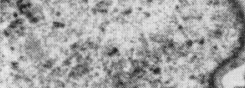

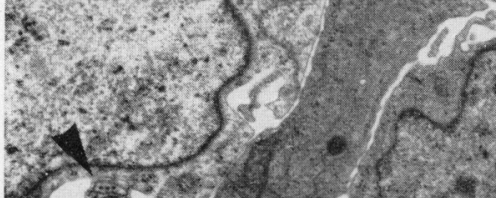

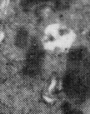

sis.

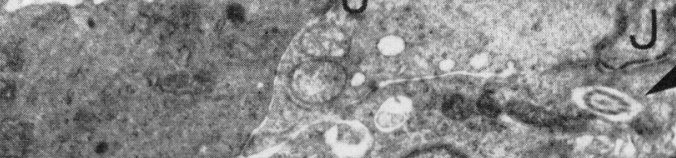

Jis

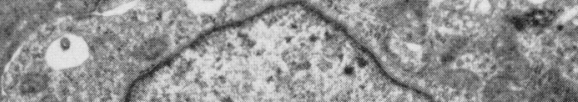

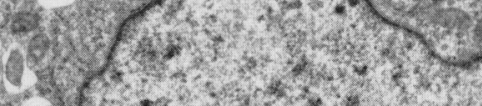

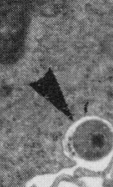
$r^{2}-$

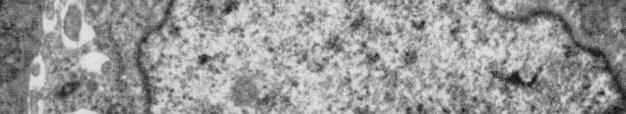

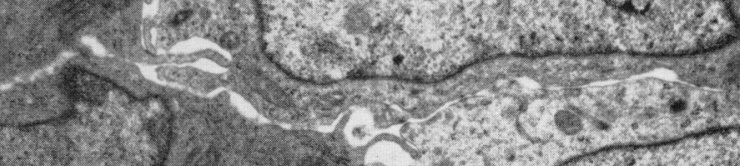

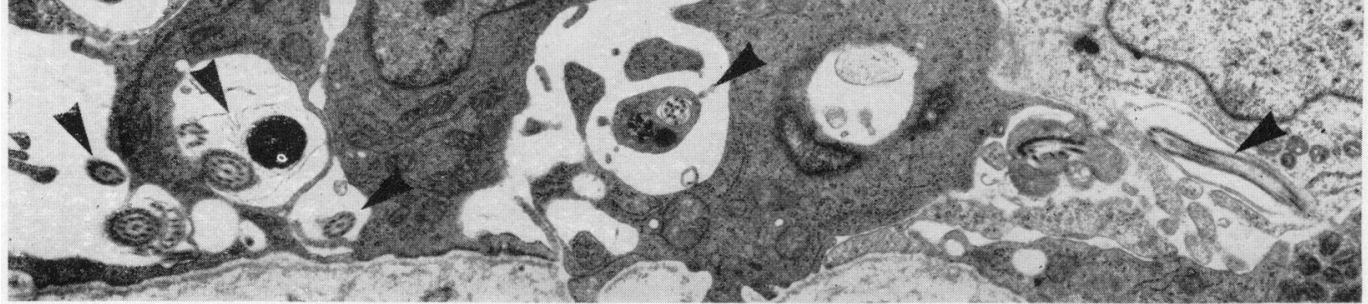




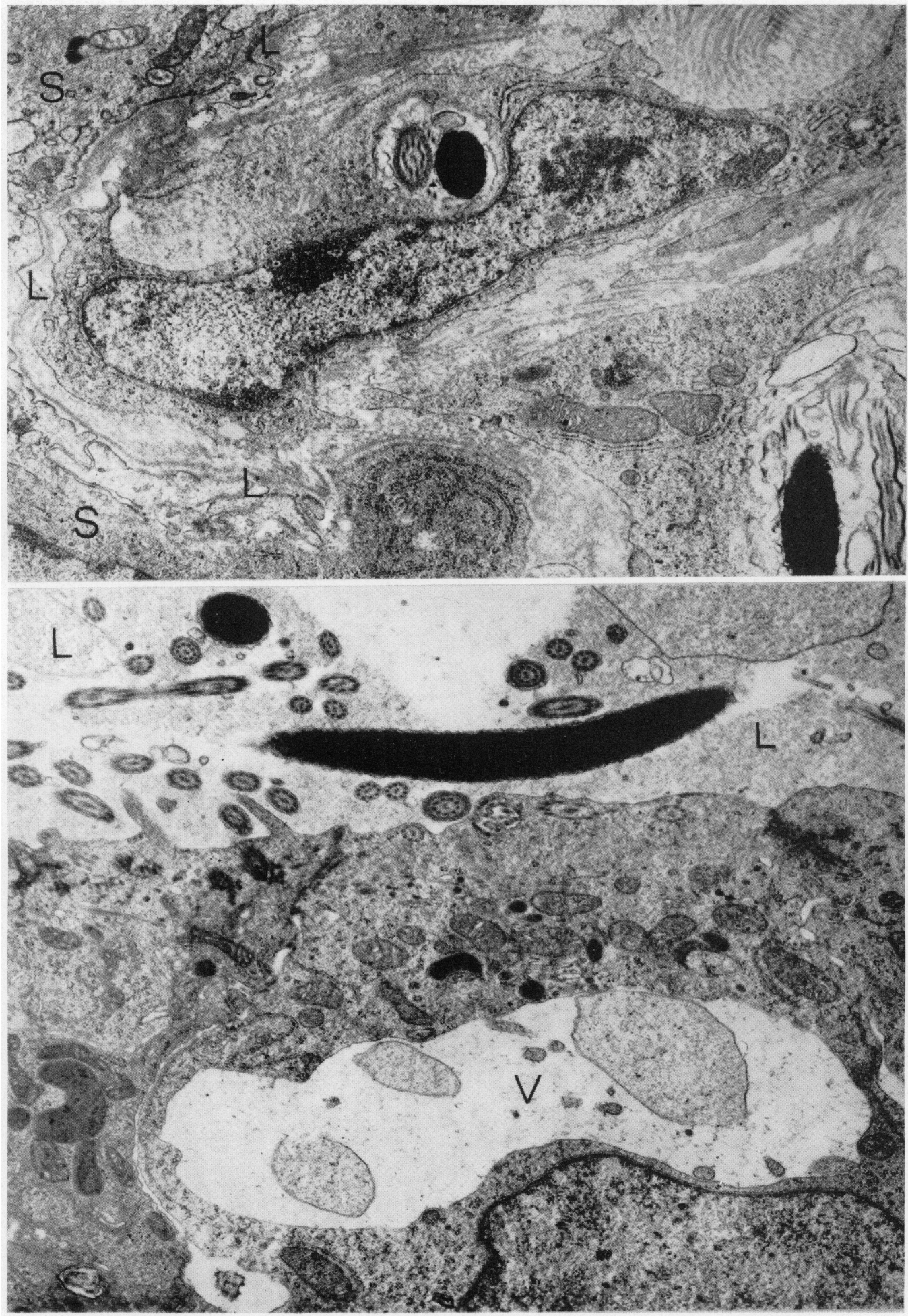




\section{Light microscopy}

Compared to the normal male, a massive accumulation of spermatozoa was evident in the lumina of the excurrent duct system cranial to the site of ligation in those birds examined 3 or 4 weeks after the operation; sometimes the lumen was almost completely occluded and this was particularly striking in the ductuli efferentes which under normal conditions have a sparse content of spermatozoa (Tingari, 1971). Free cells, débris and occasional desquamated epithelia were scattered amongst the spermatozoa in both normal and ligated tracts and, in the latter, there appeared to be an increased infiltration of the epithelia by cells with eosinophilic granules; this infiltration was particularly marked in the rete testis (Pl. 1, Fig. 1). These cells were also seen in the lumen of the expanded ducts.

The packed contents of the lumen of ligated tracts appeared to exert mechanical pressure on the normally folded wall of the ductuli efferentes (Tingari, 1971), making it appear flatter than in the control.

Many vacuolar spaces were evident within the epithelial lining of ligated excurrent ducts, mainly in the ductuli efferentes (Pl. 1, Fig. 2) and connecting ductules, and to a reduced extent in the rete testis.

\section{Electron microscopy}

Luminal contents of excurrent ducts. After 3 weeks of ligation, the lumina of excurrent ducts, particularly those of the ductuli efferentes, contained a mixture of spermatozoa, cell débris and flocculent fluid (Pl. 1, Fig. 3); the latter probably originated in the testis, as in mammals (Crabo \& Gustafsson, 1964; Setchell, 1970). Most of the spermatozoa were degenerating as shown by the disappearance of their membranes and disruption of chromatin (Pl. 1, Fig. 3). Some of the cell débris may be unidentifiable fragments of spermatozoa. No additional changes were noticed in specimens which had been ligated for more than 3 weeks.

Free phagocytic cells with an irregular shape, with or without extended processes, were present in the lumen of the more proximal ducts, namely, rete testis and ductuli efferentes (Pl. 2, Figs 4, 5); they were less common in the ductus epididymidis and ductus deferens. The number of these phagocytic cells was found to increase after ligation of the ductus deferens. They possessed cytoplasmic vacuoles containing sections of spermatozoa which were in various stages of breakdown; some spermatozoa appeared remarkably intact except for the absence of covering membranes. Profiles of rough endoplasmic reticulum, membranous whorls and electron-dense bodies, some of which were vacuolated, were evident in the cytoplasm of these luminal phagocytic cells.

The uptake of spermatozoa by the epithelial cells of the ducts. Sections of spermatozoa were seen within the cytoplasm of all the surface-lining cells in the epithelium of the excurrent ducts of control and experimental birds; the phenomenon was more evident after ligation. The low cuboidal cells of the rete testis (Pl. 3, Fig. 6), the ciliated cells (Pl. 3, Fig. 7) and the non-ciliated Type I (Pl. 3, Fig. 8) and Type II epithelial cells were involved; the Type II cells appeared to be the least active in taking up spermatozoa. Basal epithelial cells did not appear to phagocytose. The cell designations 'Type I' and 'Type II' were used by 
Tingari (1972) to distinguish two populations of non-ciliated cells present in different parts of the genital tract. Type I cells alternate with ciliated cells in the surface epithelia of the ductuli efferentes and narrow connecting ductules, whereas the Type II cells constitute the entire surface epithelia of the wide connecting ductules, the ductus epididymidis and the ductus deferens.

Sections of spermatozoa were observed surrounded by microvilli and in surface invaginations of the epithelial cells (Pl. 4, Fig. 9), in definite vacuoles in the apical and basal cytoplasm (Pl. 3, Figs 6, 7, 8) and in deep invaginations of the lateral cell membranes, i.e. the intercellular spaces (Pl. 4, Fig. 10).

The epithelium in the different regions of the ligated excurrent duct system showed no signs of mechanical damage or separation of the junctional complexes (Pl. 4, Fig. 10) in spite of the intercellular spaces, particularly towards the basal poles of the cells, being more enlarged than in the duct epithelium of the control. This feature probably explains the apparent vacuolation seen by light microscopy (Pl. 1, Fig. 2).

Phagocytic cells containing spermatozoa, which were similar morphologically to the free phagocytic cells in the lumen, were seen in the ligated tract between the basal lamina and the base of the surface epithelia (Tingari \& Lake, 1971). The spermatozoa within these cells were either incorporated wholly in cytoplasmic vacuoles or engulfed by pseudopodia-like cellular processes. The phagocytic cell was not an integral part of the epithelium. Its morphological features, taken in conjunction with its content of sperm sections, suggest that it is a type of macrophage; a similar conclusion can be reached for the phagocytic cells in the lumen.

Subepithelial macrophages. A large number of macrophages which did not contain spermatozoa were seen in the subepithelial tissue of the ducts of normal males by Tingari (1971). Following ligation of the ductus deferens, however, spermatozoa were seen in the macrophage cytoplasm (Pl. 5, Fig. 11). Some free spermatozoa were seen also in the vicinity of these cells.

Fluid uptake by the lining epithelia. Large cytoplasmic vacuoles, containing electron-lucent material of similar appearance to that of the accumulated luminal fluid, were commonly present in the apical part of the ciliated cells lining the ductuli efferentes and the narrow connecting ductules (Pl. 5, Fig. 12) in normal and ligated tracts. This is interpreted as indicating a process of fluid uptake. The vacuoles in cells of the ligated tract were more numerous and larger than those of the normal, which may indicate an intensified uptake of luminal fluid.

\section{DISGUSSION}

It is well known that several cell types with phagocytic properties are found in mammalian testes and their efferent duct systems (Shaver, 1954; Macmillan, 1957; Macmillan \& Clegg, 1961, 1963; Clegg \& Macmillan, 1961, 1965a, b; Burgos, 1964; Nicander, 1965; Sedar, 1966; Carr, Clegg \& Meek, 1968). This activity was observed in the cells after the injection of suspensions of particulate material into the duct systems of the mammals and subsequent examination by light or electron microscopy. Recently, Crabo et al. (1971) described the pres- 
ence of abnormal spermatozoa in the epithelial cells of the ductuli efferentes in a bull with subnormal testicular function. Atwal \& McFarland (1971) showed that Sertoli cells and the epithelial cells lining the excurrent ducts of the testis in Japanese quail increased their propensity for absorbing cell débris and foreign particles when the males were treated with the chlorinated insecticide, Keptone, which has oestrogenic properties.

It is considered that the present work provides conclusive evidence in the domestic fowl that cells of the surface epithelia of the excurrent duct system of the testis can phagocytose spermatozoa. The phenomenon was exaggerated by ligating the ductus deferens. The observation that the lining epithelial cells of such cocks maintained a healthy appearance and the junctional complexes were intact is considered to rule out any possibility that the luminal spermatozoa may have entered the cell cytoplasm or the intercellular spaces merely as a result of a mechanical damage to the epithelia.

Spermatozoa were often seen to be surrounded by microvilli of the surface epithelia which may be the initial step in the method of uptake. Observations were made which suggest a possible fate for the spermatozoa once they have been engulfed by the epithelial cells. Some of the phagocytosed spermatozoa may be destroyed by intracellular lysosomal activity; abundant lysosomes were observed in most of the surface epithelia lining the excurrent ducts (Tingari, 1972). However, many of the spermatozoa lay free in the intercellular spaces in the region of the base of the epithelia which could indicate that they had passed through the cells and were released at this site. They are presumably engulfed by macrophages which, when laden, pass through the basal lamina and return to their normal position in the subepithelial tissue, which might account for the appearance of the sperm-containing subepithelial macrophages.

Disintegration of luminal spermatozoa was first observed in the ductus epididymidis and ductus deferens of the guinea-pig (Young \& Simeone, 1930; Young, 1931; Simeone \& Young, 1931) and it was believed that this was one of the methods by which unejaculated spermatozoa were eliminated. Subsequent investigations by Amann \& Almquist (1962), Glover (1969) and Paufler \& Foote (1969) working with a variety of mammals agreed with Simeone \& Young (1931), but the observations were made on epididymides and regional variations in activity within epididymal segments were reported between different species. The caput epididymidis was the most active part in destroying spermatozoa in the rabbit (Paufler \& Foote, 1969), whereas the cauda epididymidis was more active in the dairy bull (Amann \& Almquist, 1962). In the domestic fowl, luminal disintegration of spermatozoa appeared to occur mainly in the ductuli efferentes and was particularly noticeable 3 weeks after ligation. Various authors have discussed the ultimate fate of the products of the breakdown of spermatozoa in the lumen of the male reproductive tract of vertebrates. Young \& Simeone (1930) and Simeone \& Young (1931) considered the possibility of their voidance in urine and/or ingestion by the epithelial cells of the excurrent ducts. In a study of the ligated epididymis in the rabbit, Glover (1969) also suggested that the lining cells of this duct ingested disintegrating spermatozoa. The luminal macrophages in the fowl which ingest spermatozoa may be similar to those described by Holstein (1967) in the human 
epididymis. The mechanism by which these cells get access to the lumen remains unknown. Their final fate is also not clear; they may themselves undergo disintegration in situ, and the cellular fragments or the intact cells may be disposed of through the epithelium in the same manner as the products of disintegrating spermatozoa.

It is concluded from this study that luminal disintegration, uptake by surface epithelia lining the entire male genital tract and phagocytosis by luminal and tissue macrophages are among the factors concerned in the disposal of unejaculated spermatozoa in the reproductive tract of the domestic fowl. Further quantitative studies are required before the physiological significance of these cellular processes, in the functions of the male tract, can be fully understood.

The testicular fluids may undergo resorption in the ciliated cells lining the ductuli efferentes and narrow connecting ductules; vacuoles suggesting such a process were observed in other cells. Such resorption may offer an explanation for the sparsity of spermatozoa in the lumina of the rete testis and ductuli efferentes and their great concentration caudally in the ducts in the normal male (Tingari, 1971). It is well known in mammals that most of the fluid produced in the seminiferous tubules is resorbed in the ductuli efferentes and the proximal part of the ductus epididymidis (Mason \& Shaver, 1952; Crabo \& Gustafsson, 1964; Setchell, 1970).

\section{ACKNOWLEDGMENTS}

We are grateful to Professor A. R. Muir for helpful comments and advice. One of us (M.D.T.) wishes to thank the Population Council for a fellowship.

\section{REFERENCES}

Amans, R. P. (1962) Reproductive capacity of dairy bulls. III. The effect of ejaculation frequency, unilateral vasectomy, and age on spermatogenesis. Am. J. Anat. 110, 49.

Amann, R. P. (1970) Sperm production rates. In: The Testis, Vol. I, p. 433. Eds. A. D. Johnson, W. R. Gomes and N. L. VanDemark. Academic Press, New York and London.

Amann, R. P. \& AlmQuist, J. O. (1962) Reproductive capacity of dairy bulls. IV. Effects of unilateral vasectomy and ejaculation frequency on sperm reserves; aspects of epididymal physiology. $\mathcal{F}$. Reprod. Fert. 10, 241.

Atwal, O. S. \& McFarLand, L. Z. (1971) Carbon uptake response by Sertoli cells and epithelial cells lining the duct system of the Japanese quail (Coturnix coturnix japonica). Poult. Sci. 50, 159.

BIELANSKI, W. \& WIERzBOWSKI, S. (1961) Attempts at determination of the daily output of spermatozoa in rams on the basis of the so-called 'Depletion Test' carried out at varying intervals. Proc. 4th int. Congr. Anim. Reprod., The Hague, 2, 274.

Burgos, M. H. (1964) Uptake of colloidal particles by cells of the caput epididymidis. Anat. Rec. 148, 517.

CarR, I., CleggG, E. J. \& Meek, G. A. (1968) Sertoli cells as phagocytes: an electron microscopic study. F. Anat. 102, 501.

ClegG, E. J. \& Macmillan, E. W. (1961) Observations on the uptake of trypan blue by the seminiferous tubules of the rat testis. F. Anat. 95, 615p.

CLEGG, E. J. \& MACMILLAN, E. W. (1965a) The uptake and storage of particulate matter by the interstitial cells of the rat testis. F. Anat. 99, 204p.

Clegg, E. J. \& MaCMILLAN, E. W. (1965b) The uptake of vital dyes and particulate matter by the Sertoli cells of the rat testis. F. Anat. 99, 219.

Grabo, B. \& Gustafsson, B. (1964) The distribution of sodium and potassium and its relation to sperm concentration in the epididymal plasma of the bull. F. Reprod. Fert. 7, 337.

Crabo, B., Gustafsson, B., Nicander, L. \& Rao, A. R. (1971) Subnormal testicular function in a bull 
concealed by phagocytosis of abnormal spermatozoa in the efferent ductules. F. Reprod. Fert. 26, 393.

Foote, R. H. (1962) The use of radioactive isotopes to study spermatogenesis and transport of spermatozoa in mammals. A review. Symp. Gen. Biol. Italica, 9, 55.

GLover, T. D. (1969) Some aspects of function in the epididymis. Experimental occlusion of the epididymis in the rabbit. Int. J. Fert. 14, 215.

Holstern, A.-F. (1967) Spermiophagen im Nebenhoden des Menschen. Naturwissenschaften, 54, 98.

Livo, B. F., Braden, A. W. H. \& Turnbuls, K. E. (1967) Fate of unejaculated spermatozoa. Nature, Lond. 213, 594.

Magmillan, E. W. (1957) The caput epididymidis and trypan blue. F. Anat. 9, 616p.

Macmillan, E. W. \& ClegG, E. J. (1961) The transport of trypan blue by the seminiferous tubules of the rat testis. 7. Anat. 95, 615P.

Macmilan, E. W. \& CLEGG, E. J. (1963) Observations on the uptake of Indian ink by the seminiferous tubules and the excurrent duct system of the rat testis. F. Anat. 97, 154r.

Mason, K. E. \& Shaver, S. L. (1952) Some functions of the caput epididymidis. Ann. N.Y. Acad. Sci. 55,585 .

MrLionig, G. (1962) Further observations on a phosphate buffer for osmium solutions in fixation. Proc. 5 th int. Congr. Electron Microsc. Vol. II, p. P-8. Ed. S. S. Breese. Academic Press, New York and London.

NiCANDER, L. (1963) Resorption phenomena in the epididymis. Int. F. Fert. 8, 866.

NICANDER, L. (1965) An electron microscopical study of absorbing cells in the posterior caput epididymidis of rabbits. Z. Zellforsch. mikrosk. Anat. 66, 829.

Orgebin-CRIsT, M. G. (1965) Passage of spermatozoa labelled with thymidine- ${ }^{3} \mathrm{H}$ through the ductus epididymidis of the rabbit. F. Reprod. Fert. 10, 241.

Oszund, R. M. (1928) The physiology of the male reproductive system. F. Am. med. Ass. 1, 829.

PaUfler, S. K. \& Foote, R. H. (1969) Sperm retention and resorption in sexually active rabbits with epididymal ligatures. Proc. Soc. exp. Biol. Med. 131, 1179.

REYNoLDs, E. S. (1963) The use of lead citrate at high $\mathrm{pH}$ as an electron-opaque stain in electron microscopy. F. Cell Biol. 17, 208.

Sedar, A. W. (1966) Transport of exogenous peroxidase across the epididymal epithelium. Int. Conf. Electron. Microsc., Kyoto, Japan, Vol. 2, p. 591. Ed. R. Uyeda. Maruzen Co. Ltd, Tokyo.

Setchers, B. P. (1970) Testicular blood supply, lymphatic drainage and secretion of fuid. In: The Testis, Vol. I, p. 101. Eds. A. D. Johnson, W. R. Gomes and N. L. VanDemark. Academic Press. New York and London.

Shaver, S. L. (1954) The role of stereocilia in removing India ink from the lumen of the rat epididymis. Anat. Rec. 119, 177.

Simeone, F. A. \& Young, W. G. (1931) A study of the function of the epididymis. IV. The fate of non-ejaculated spermatozoa in the genital tract of the male guinea-pig. F. exp. Biol. 8, 163.

StEMPAK, J. G. \& WARD, R. T. (1964) An improved staining method for electron microscopy. F. Cell Biol. 22, 697.

Tingarr, M. D. (1971) On the structure of the epididymal region and ductus deferens of the domestic fowl (Gallus domesticus). 7. Anat. 109, 423.

Tingari, M. D. (1972) The fine structure of the epithelial lining of the excurrent duct system of the testis of the domestic fowl (Gallus domesticus). Q. Jl exp. Physiol. 57, 271.

Tingari, M. D. \& LAKE, P. E. (1971) Uptake of spermatozoa by the ductuli efferentes after ligation of the ductus deferens of the domestic fowl. F. Anat. 109, 353.

Younc, W. C. (1931) A study of the function of the epididymis. III. Functional changes undergone by spermatozoa during their passage through the epididymis and vas deferens in the guinea-pig. $\mathcal{F}$. exp. Biol. 8, 151.

Young, W. C. \& Simeone, F. A. (1930) Development and fate of spermatozoa in the epididymis and vas deferens in the guinea-pig. Proc. Soc. exp. Biol. Med. 27, 838. 